GHÂNCARAN: JURNAL PENDIDIKAN
$\begin{aligned} & \text { BAHASA DAN SASTRA INDONESIA } \\ & \frac{\text { http://ejournal.iainmadura.ac.id/index.php/ghancaran }}{\text { E-ISSN : 2715-9132; P-ISSN: } 2714-8955} \\ & \text { DOI 10.19105/ghancaran.v3i2.3528 }\end{aligned}$

\title{
Analisis Tindak Tutur Ilokusi Akun Baksosapi.gapakemicin dalam Unggahan di Instagram (Suatu Analisis Pragmatik)
}

\author{
Melly Vila Melanii, Asep Purwo Yudi Utomo* \\ *Bahasa dan Sastra Indonesia, Universitas Negeri Semarang \\ **Bahasa dan Sastra Indonesia, Universitas Negeri Semarang \\ Alamat surel:mellyvilamelani@gmail.com; aseppyu@mail.unnes.ac.id
}

\begin{tabular}{|c|c|}
\hline & Abstract \\
\hline \multirow[t]{2}{*}{$\begin{array}{l}\text { Keywords: } \\
\text { illocution; } \\
\text { instagram; } \\
\text { social media; } \\
\text { pragmatics }\end{array}$} & $\begin{array}{l}\text { This study focuses on the use of speech act in pragmatic mainly } \\
\text { focused on illocution act on Baksosapi.gapakemicin instagram } \\
\text { account. This research used descriptive method by observing } \\
\text { research objects. The data resource in this research is illocution act } \\
\text { on Baksosapi.gapakemicin instagram account which are } \\
\text { straightforward and meaningful language. Austin's theory was used } \\
\text { to assess and analyze the situation, representative, directive, } \\
\text { expressive, commissive, and directive in the presence of evidence of } \\
\text { uploads and analyzed from Searle. The result of this research } \\
\text { showed that speech act which is often used in } \\
\text { Baksosapi.gapakemicin instagram account is illocution act, although } \\
\text { it tends to show joke or unclear text. However, this account has a } \\
\text { great influence to reader dealing with something that has been } \\
\text { written in the upload. }\end{array}$ \\
\hline & Abstrak: \\
\hline $\begin{array}{l}\text { Kata Kunci: } \\
\text { llokusi; } \\
\text { Instagram; } \\
\text { media sosial; } \\
\text { pragmatik }\end{array}$ & $\begin{array}{l}\text { Penelitian ini berfokus pada penggunaan tindak tutur dalam } \\
\text { pragmatik, utamanya terfokus pada tindak tutur ilokusi akun } \\
\text { instagram Baksosapi.gapakemicin. Penelitian ini menggunakan } \\
\text { metode penelitian deskriptif dengan cara mengamati objek } \\
\text { penelitian. Sumber data penelitian ini dari akun } \\
\text { Baksosapi.gapakemicin yang mengandung tindak tutur ilokusi } \\
\text { dengan bahasa yang lugas dan bermakna. Dalam penelitian ini } \\
\text { menggunakan teori Austin, yaitu representatif, direktif, ekspresif, } \\
\text { komisif, dan direktif dengan adanya bukti-bukti unggahan dan } \\
\text { analisis dari Searle. Hasil penelitian ini menunjukkan bahwa tindak } \\
\text { tutur yang sering digunakan dalam akun Baksosapi_unnes } \\
\text { menggunakan tindak tutur ilokusi, walaupun cenderung } \\
\text { menampakkan guyonan atau hal-hal tidak jelas dalam tulisannya. } \\
\text { Namun, akun tersebut memiliki pengaruh yang besar untuk } \\
\text { mempengaruhi pembaca terkait suatu hal yang sudah ditulis dalam } \\
\text { unggahannya. }\end{array}$ \\
\hline Terkirim : 24 Juni 2020 & (0 $\quad$; Revisi: 28 Januari 2022 ; Diterima: 31 Januari 2022 \\
\hline (C)Ghâncé & $\begin{array}{l}\text { Iaran: Jurnal Pendidikan Bahasa dan Sastra Indonesia } \\
\text { Tadris Bahasa Indonesia } \\
\text { nstitut Agama Islam Negeri Madura, Indonesia }\end{array}$ \\
\hline
\end{tabular}




\section{PENDAHULUAN}

Dalam KBBI, yang dimaksud dengan tuturan adalah sesuatu yang dituturkan; ucapan; ujaran (KBBI, 2016). Tuturan adalah suatu ujaran dari seorang penutur terhadap mitra tutur ketika sedang berkomunikasi. Tuturan dalam pragmatik diartikan sebagai produk suatu tindak verbal (bukan tindak verbal itu sendiri) (Leech, 1983). Tuturan yang memiliki sifat psikologis dan keberlangsungannya ditentukan oleh kemampuan berbahasa penutur dalam menghadapi situasi tertentu dikatakan sebagai tindak tutur (Chaer, 2010). Tuturan dapat diekpresikan melalui media lisan maupun tulisan. Perkembangan zaman dengan diiringi dengan perkembangan teknologi mampu membuat seseorang mengekspresikan dirinya melalui sebuah media yang terhubung kepada seluruh jaringan manusia di dunia. Jaringan tersebut biasa kita sebut dengan media sosial. Kita dapat menggunakannya untuk menyalurkan ide, gagasan, pikiran, dan menyampaikan informasi kepada orang lain melalui bahasa secara lisan maupun tulisan.

Perkembangan teknologi media sosial yang mewabah di dunia menjadi wadah manusia untuk berinteraksi antarmanusia. Begitu eksisnya media sosial di semua kalangan usia, seperti instagram. Media sosial ini dapat mengunggah foto, video, dan cerita kita sehari-hari. Survei WeAreSocial.net dan Hootsuite ditahun 2019, instagram mempunyai pengguna terbanyak ketujuh di dunia sebagai platform media sosial (Hootsuite, 2019). Instagram tercatat dalam urutan ketiga setelah Amerika dan Brasil dalam catatannya sebagai pengguna aktif media sosial terbanyak ketiga di dunia. Salah satu akun Instagram yang menarik untuk dikaji, yaitu akun Baksosapi.gapakemicin. Akun tersebut aktif di media sosial Instagram untuk mempersuasi yang disertai dengan humor.

Bahasa merupakan sistem lambang bunyi arbiter yang digunakan untuk bekerja sama, berinteraksi, dan mengidentifikasi (Setyawan, 2016). Bahasa disebut juga salah satu alat komunikasi yang mampu memunculkan pemahaman kepada mitra tutur pada saat sedang bertukar informasi (Sjafii, 2021). Dengan bahasa, ide gagasan dapat dikemukakan, baik secara lisan ataupun tulis. Selain itu, bahasa adalah sarana utama untuk memperoleh pengetahuan seseorang di dalam dunia. Untuk representasi mental transmisi dan menjadikannya bagian umum dan dapat diakses secara intersubjektif (Oktapiantama \& Utomo, 2021).

Penelitian ini relevan dengan penelitian yang sudah ada sebelumnya. Penelitian ini sudah pernah dikaji dalam jurnal penelitian dengan judul "Tindak Tutur llokusi Pada Video Story Time With Jovi di Media Sosial Youtube" (Asry, 2017). Perbedaan artikel ini dengan penelitian sebelumnya terdapat pada bahan kajian yang diambil. Penelitian ini mengambil sebuah unggahan di instagram dan mengaitkannya dengan kehidupan 
Melly Vila Melani, Asep Purwo Yudi Utomo

sehari-hari, sedangkan penelitian sebelumnya meneliti tindak tutur pada sebuah akun youtube.

Pragmatik berkaitan dengan makna dalam konteks dengan tujuan dapat menganalisis dari berbagai sudut pandang (perspektif pembicara, penerima, analisis, dll). Pragmatik menjembatani kesenjangan antara sistem bahasa dan sisi penggunaannya. Salah satunya pragmatik mempelajari mengenai teori tindak tutur (Kusumawati \& Innayah, 2020). Menurut Austin, tindak tutur dapat dianalisis pada tiga tingkatan, yaitu lokusi (ujaran yang aktual dan maknanya yang jelas), ilokusi (ujaran yang dihasilkan dari permintaan atau makna tersirat), dan perlokusi (dampak sebenarnya dari tindak lukosi) (Rembe, Frieda Th Jansen, \& Jeane A. Manus, 2020).

Tindak tutur ilokusi merupakan suatu tindak tutur dalam melakukan sesuatu hal dan mengandung tuturan. Tindak tutur ilokusi berkaitan dengan siapa, kapan, dan di mana tindak tutur tersebut dilakukan. Searle membagi jenis tindak tutur ilokusi menjadi dalam lima jenis, yaitu: representatif, direktif, ekspresif, komisif, dan deklaratif (Searle, 1969). Tindakan ilokusi dapat ditemukan dalam kehidupan sehari-hari, dari tulis hingga lisan (Verawati \& Mulyadi, 2019). Dalam maraknya media sosial dikalangan dunia, menimbulkan banyak tuturan yang menarik untuk dikaji dalam ilmu pragmatik, seperti instagram, youtube, twitter, dan lain sejenisnya.

Fungsi ilokusi dapat diklasifikasikan menjadi empat jenis (Searle, 1969). Pertama, fungsi kompetitif yang merupakan suatu tuturan yang tidak bertatakrama, yang memiliki tujuan dalam mengurangi keharmonisan. Jenis ini ditandai dengan adanya verba perintah, menutut, juga mengemis (Putikadyanto \& L. Khomsiyah, 2021). Kedua, fungsi untuk menyenangkan. Fungsi ini memiliki arti bahwa dalam suatu tuturan yang memiliki tatakrama dan dengan tujuan mencari kesempatan mendekatkan diri beramah tamah. Jenis ini ditandai dengan verba tawarkan, undangan, mengucapkan selamat, mengucapkan terima kasih, dan menyapa. Ketiga, fungsi bekerja sama. Bekerja sama bertujuan untuk tidak melibatkan tujuan sosial, yang biasanya ditandai dengan verba melaporkan, menyatakan, mengumumkan, dan mengajarkan. Keempat fungsi bertentangan. Jenis fungsi bertentangan merupakan tindak tutur yang sama sekali tidak melibatkan unsur tatakrama, dengan tujuan menimbulkan kemarahan, ditandai dengan verba memarahi, mengancam, menyumpahi, dan menuduh.

Penelitian ini memiliki tujuan untuk memberikan identifikasi mengenai tindak tutur ilokusi pada unggahan akun Baksosapi.gapakemicin di media sosial instagram. Selain itu, penelitian ini untuk mengetahui fungsi dari tindak tutur ilokusi yang digunakan oleh akun Baksosapi.gapakemicin dalam unggahannya di media sosial. Media sosial 
merupakan penyedia platform terbanyak yang digunakan oleh manusia, sehingga menarik jika untuk dijadikan penelitian.

Manfaat penelitian ini terbagi menjadi dua. Secara teoretis, penelitian ini dapat memberikan kontribusi untuk studi linguistik terutama pada bidang ilmu pragmatik khususnya tindak ilokusi. Secara praktis, penelitian ini dapat memberikan kontribusi kepada pembaca untuk memahami lebih mendalam tentang tindak tutur ilokusi. Selain itu, manfaat untuk kehidupan sehari-hari dapat menjadikan pembaca dalam suatu unggahan di media sosial dapat lebih teliti dalam memahami dari sudut pandang pragmatik, sehingga pembaca dapat menangkap isi secara meneyeluruh.

\section{METODE}

Penelitian ini menggunakan pendekatan kualiatif dengan metode deskriptif. Metode deskriptif dapat diartikan sebagai prosedur pemecahan suatu masalah yang diselidiki dengan menggambarkan keadaan subjek atau objek di dalam seuatu penelitian (Moleong, 2013). Sumber data penelitian ini dari unggahan Instagram akun Baksosapi.gapakemicin. Penelitian ini menggunakan kajian tindak tutur dari pandangan Austin yang diperkuat dengan pandangan Searle. Dalam penelitian ini pengumpulan dan analisis data dilakukan dengan beberapa langkah. Pertama, penulis membaca referensi yang terkait dengan penelitian, termasuk membaca berbagai referensi yang mengkaji tentang tindak ilokusi. Kedua, penulis mengamati unggahan akun Baksosapi.gapakemicin untuk lebih cermat dan teliti dalam penelitian. Ketiga, pengumpulan data dan penulis mengidentifikasikannya. Keempat, mengklasifikasi semua tindak ujar ilokusi dan di tulis di kertas kecil kemudian diberi nomor sesuai dengan unggahan akun serta tanggal diunggah secara acak. Kelima, menganalisis data data yang sudah diidentifikasi. Keenam, yaitu mengklasifikasi berdasarkan teori Austin.

\section{HASIL DAN PEMBAHASAN}

Tindak ilokusi merupakan suatu ujaran yang dihasilkan dari permintaan atau makna tersirat yang disajikan oleh tindak ujar ilokusi, misalnya jika tindak ujar ilokusi dalam interaksi akan pertanyaannya (Austin, 1965). Akun Instagram Baksosapi.gapakemicin adalah akun yang dibuat untuk media kampanye pemilihan presiden mahasiswa UNNES tahun periode 2019/2020. Akun tersebut sampai sekarang masih eksis di instagram dengan unggahan dengan bahasa ringan dan bersahabat. Ungkapan, sindiran, keluhan dan kritik diunggahnya dengan kreatif dan bahasa menggelitik. Dalam penelitian analisis 
tindak tutur ilokusi akun Baksosapi.gapakemicin di Instagram ini terdapat 5 jenis tidak tutur ilokusi, berikut penjabarannya.

\section{Representatif}

Tindak tutur representatif adalah suatu tindak tutur yang menyatakan kebenaran dari ujaran yang bersifat mengikat penuturnya. Contoh dengan mengakui, menyatakan, melaporkan, memberikan kesaksian, menunjukkan, berspekulasi dan lainnya. Berikut merupakan salah satu unggahan yang berupa tindak tutur ilokusi representatif:

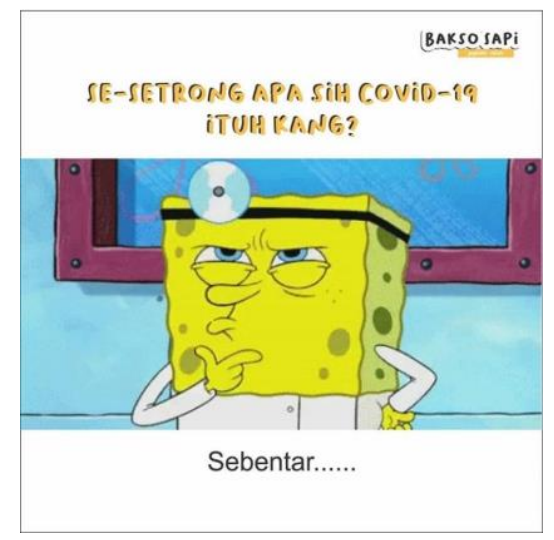

Gambar 1. Contoh gambar tindak tutur representatif

(Baksosapi.gapakemicin, 2020c)

Dalam unggahan akun tersebut, penutur memberikan kebenaran atas ucapan dalam unggahan di Instagram tentang bahayanya coronavirus atau biasa disebut dengan Covid-19. Selain itu, penutur menyatakan dalam unggahan tersebut mengandung pernyataan tentang definisi, jangka waktu penyebaran, cara penyebaran dari berbagai jenis barang yang dapat menyebarkan virus Covid-19. Kemudian terdapat pertanyaan cara menanggulangi kesebaran virus tersebut dengan memberikan spekulatif menggunakan antiseptik.

Dalam unggahan tersebut, penutur berusaha menyatakan kebenaran dengan cara yang unik sehingga mempengaruhi pembaca dalam kebenaran mengantisipasi penularan virus Covid-19 yang sedang mewabah. Mempengaruhi pembaca merupakan tujuan tindak tutur ilokusi, memberi pernyataan penting dengan dikemas secara ringan dan unik merupakan inovasi penyebaran berita yang efektif di media sosial.

\section{Direktif}

Direktif merupakan suatu tindak tutur yang memiliki tujuan yang dimaksudkan penutur agar mitra tutur dapat melakukan tindakan yang disebutkan dalam tuturan, seperti memerintah, memaksa, mengajak, memohon, menyuruh, menyarankan, 
meminta, memberikan aba-aba dan lainnya. Berikut merupakan salah satu unggahan yang berupa tindak tutur ilokusi direktif.

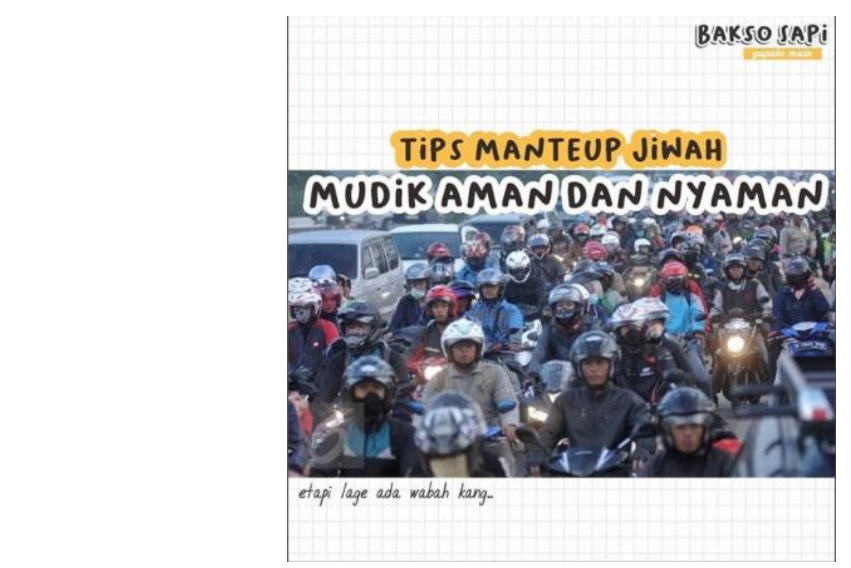

Gambar 2. Contoh tindak tutur direktif (Baksosapi.gapakemicin, 2020d)

Dalam unggahan akun Baksosapi.gapakemicin memiliki ujaran yang mempengaruhi pembaca untuk melakukan suatu tindakan, seperti pada unggahan dengan judul Tips Manteup Jiwa Mudik Aman dan Nyaman. Penutur memberikan tips mudik aman dan nyaman dengan bahasa khas penutur yang disajikan dalam beberapa slide. Hal tersebut berisi imbauan menggunakan helm, cek info perjalanan, dan tips lain yang dapat pembaca terapkan untuk perjalanan mudik aman.

Unggahan tersebut bernada tegas mengimbau pemudik untuk menjaga keselamatan di jalan sehingga tuturan digunakan untuk mempengaruhi pembaca. Penutur menggunakan bahasa kiasan dengan diksi yang gaul sehingga mudah diterima oleh pembaca yang mayoritas adalah mahasiswa.

\section{Ekspresif}

Tindak tutur ekspresif merupakan sauatu tindak tutur yang memiliki maksud penutur supaya ujarannya diartikan oleh mita tutur sebagai evaluasi, seperti mengkritik, memuji, mengeluh, mengucapkan terima kasih, dan menyalahkan. Berikut merupakan salah satu unggahan yang berupa tindak tutur ilokusi ekspretif. 


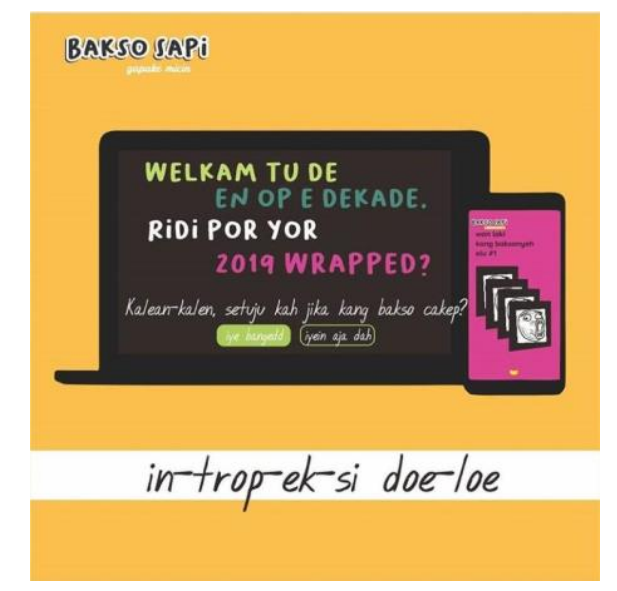

Gambar 3. Contoh tindak tutur ilokusi ekspresif (Baksosapi.gapakemicin, 2019)

Unggahan akun Baksosapi.gapakemicin pada 8 Desember 2019 merupakan tulisan penulis yang mengungkapkan kritik dan bertujuan untuk dapat menjadi evaluasi bersama bagi pembaca. Tulisan tersebut menggunakan bahasa yang ringan dan pemilihan diksi yang kekinian. Hal itu merupakan kekhasaan penulis dalam mempengaruhi pembaca untuk turut mengevaluasi diri. Unggahan tersebut dapat tergolongkan dalam tindak tutur ilokusi jenis ekspresif karena dilihat dari tujuan penulis dan ekspresi penulis dalam unggahannya tersebut. Tulisan yang disajikan memiliki tujuan mempengaruhi penulis dengan mengeritik dan mengevaluasi suatu hal dengan pembaca, sehingga maksud dan tulisan penulis dapat tersampaikan dengan baik.

\section{Komisif}

Tindak tutur komisif merupakan sebuah tindak tutur yang memiliki sifat mengikat supaya melakukan apa yang telah disebutkan di dalam tuturannya, contohnya mengancam, bernazar dan berjanji. Berikut merupakan salah satu unggahan yang berupa tindak tutur ilokusi komisif:

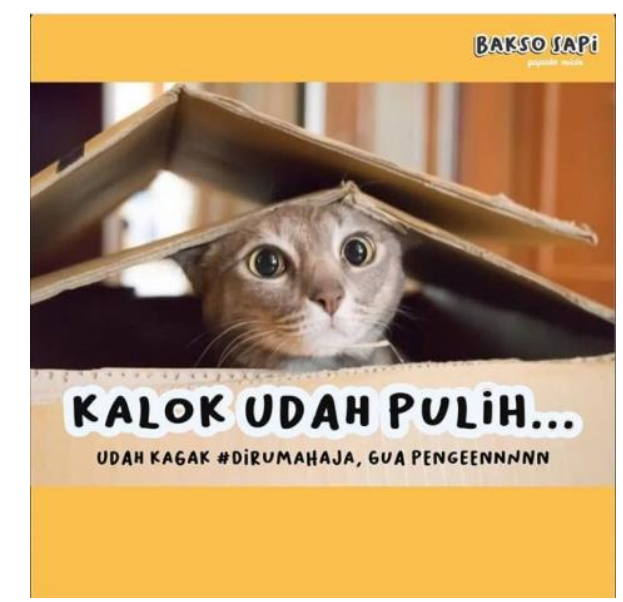

Gambar 4. Contoh tindak tutur ilokusi komisif (Baksosapi.gapakemicin, 2020b) 
Dalam unggahan akun Baksosapi.gapakemicin tanggal 11 April 2020 tergolong pada tindak tutur komisif. Penulis menyampaikan apa yang akan ia lakukan dalam suatu hal atau situasi tertentu. Penulis melaksanakannya sesuai apa yang dia ucapkan atau tuliskan. Hal itu dapat disebut dengan nazar atau suatu janji. Dalam unggahannya, penulis menyampaikan bahwa jika nanti keadaan sudah pulih dari virus corona, penulis akan melakukan apa yang penulis tuliskan, seperti jalan-jalan, berenang, dan lain-lain, sehingga unggahan tersebut termasuk dalam tindak tutur ilokusi komisif. Selain itu, unggahan tersebut juga mengikat pembaca dengan mengungkapkan keinginan penulis melalui tulisannya, sehingga pembaca juga akan berpikir dan merancang hal apa yang akan dilakukannya jika pandemi virus corona ini sudah berakhir.

\section{Deklaratif}

Tindak tutur deklaratif merupakan tindak tutur yang memiliki maksud untuk menciptakan suatu hal baru, seperti keadaan, status, dan lain sebagainya. Tindak tutur tersebut lazimnya untuk mengizinkan, menggolongkan, mengesahkan, memutuskan, membatalkan, melarang, mengangkat, mengampuni, mengabulkan, dan memaafkan. Berikut merupakan salah satu unggahan yang berupa tindak tutur ilokusi deklaratif.

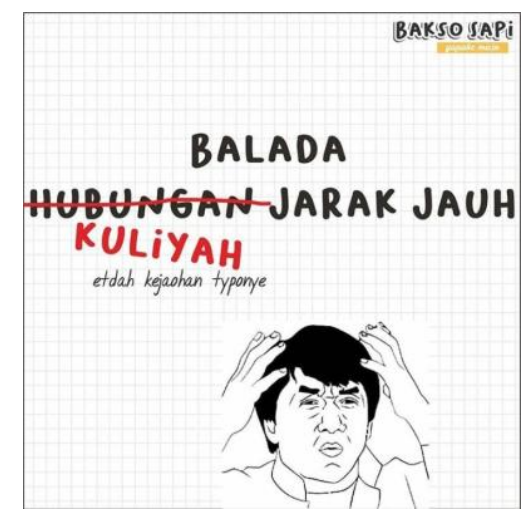

Gambar 5. Contoh tindak tutur deklaratif (Baksosapi.gapakemicin, 2020a)

Unggahan "Balada Kuliyah Jarak Jauh" merupakan unggahan yang dimaksudkan untuk menciptakan suatu hal baru di tengah situasi pandemi yang dialami oleh mahasiswa. Perubahan tersebut terdapat pada sistem perkuliahan luring berubah menjadi daring dengan batas waktu yang belum bisa ditentukan. Penulis menuliskannya dalam akun Baksosapi.gapakemicin sebagai bentuk aduan atas keadaan baru yang dialaminya saat ini sehingga berpengaruh terhadap perkuliahan dengan media sosial. Oleh karena itu, tuturan ini merupakan tindak tutur ilokusi deklaratif. 


\section{SIMPULAN}

Berdasarkan analisis yang telah dilakukan dapat disimpulkan bahwa tindak tutur yang sering digunakan dalam akun Baksosapi.gapakemicin menggunakan tindak tutur ilokusi, walaupun cenderung menampakkan guyonan atau hal-hal tidak jelas dalam tulisannya. Namun hal tersebut memiliki pengaruh yang besar untuk memengaruhi pembaca pada apa yang sudah ditulis dalam unggahannya. Pembaca dapat lebih cermat dalam membaca atau menganalisis suatu tuturan atau tulisan untuk lebih memahami maksud dari penulis atau penutur, karena dalam sebuah tulisan walau seringan apa pun tulisannya pasti memberikan pengaruh dan berisi pesan yang disampaikan kepada pembaca dengan cara masing-masing.

\section{DAFTAR RUJUKAN}

Asry, A. (2017). Tindak Tutur Ilokusi pada Video Story Time With Jovi di Media Sosial Youtube. Universitas Diponegoro, Semarang.

Austin. (1965). How to do Things with Words. New York: Oxford University Press.

Baksosapi.gapakemicin. (2019). Welkam tu de en op e Dekade. Ri di or yor 2019 wrapped. Retrieved from Instagram website: https://www.instagram.com/p/B5y0rVSFZSt/?utm_source=ig_web_copy_link

Baksosapi.gapakemicin. (2020a). Balada Kuliyah Jarak Jauh. Retrieved from Instagram website:

https://www.instagram.com/p/B920tRPF2Os/?utm_source=ig_web_copy_link

Baksosapi.gapakemicin. (2020b). Kalok Udah Pulih... udah kagak \#dirumahaja gua pengeennnnn. Retrieved from Instagram website: https://www.instagram.com/p/B2E7O8IsLJ/?utm_source=ig_web_copy_link

Baksosapi.gapakemicin. (2020c). Se-seterong apa sih Covid-19 ituh Kang? Retrieved from Instagram website: https://www.instagram.com/p/B9ya0XzIT6L/?utm_source=ig_web_copy_link

Baksosapi.gapakemicin. (2020d). Tips Manteup Jiwa Mudik Aman dan Nyaman. Retrieved from Instagram website: https://www.instagram.com/p/BSL1JmpXyC/?utm_source=ig_web_copy_link

Chaer, A. (2010). Kesantunan berbahasa. Rineka Cipta.

Data hasil riset Wearesosial Hootsuite. (2019). Retrieved from https://websindo.com/indonesia-digital-2019-media-sosial/

Kamus Besar Bahasa Indonesia (KBBI). (2016). In KBBI. Badan Pengembangan dan Pembinaan Bahasa.

Kusumawati, H., \& Innayah, I. (2020). Tindak Tutur dalam Tradisi Pernikahan Masyarakat Madura pada Era Millenial: Kajian Sosiopragmatik. GHANCARAN: Jurnal Pendidikan Bahasa dan Sastra Indonesia.

Leech, G. (1983). The Principle of Pragmatics. Cambridge: Cambridge University Press. Moleong, L. J. (2013). Metodologi Penelitian Kualitatif. Bandung: Remaja Rosdakarya.

Oktapiantama, H., \& Utomo, A. P. Y. (2021). Analisis Tindak Tutur Direktif pada Film Keluarga Cemara Karya Yandy Laurens. GHANCARAN: Jurnal Pendidikan Bahasa Dan Sastra Indonesia, 2(2), 76-87.

Putikadyanto, A., \& L. Khomsiyah. (2021). Tindak Tutur llokusi pada Wawancara Kursi Kosong di Acara Mata Najwa. Jurnalfkip.Universitas-Samawa.Ac.ld, 1(2).

Rembe, P. K., Frieda Th Jansen, \& Jeane A. Manus. (2020). Tindak llokusi dalam Film Divergent Series Insurgent Karya Robert Schwentke (Suatu Analisis Pragmatik). 
Urnal Elektronik Fakultas Sastra Universitas Sam Ratulangi, 11.

Searle, J. . (1969). Speech Act. London: Cambridge University Press.

Setyawan, F. H. (2016). Meningkatkan Kemampuan Berbahasa Anak Usia Dini Melalui Model Pembelajaran Audio Visual Berbasis Android. Jurnal PG-PAUD Trunojoyo: Jurnal Pendidikan Dan Pembelajaran Anak Usia Dini, 3(2), 92-98.

Sjafii, N. A. D. (2021). Bahasa Pengantar Peminjaman Uang Masyarakat Kampung Manten Kecamatan Kota Pamekasan. GHANCARAN: Jurnal Pendidikan Bahasa Dan Sastra Indonesia, 2(2), 151-160.

Verawati, F., \& Mulyadi, M. (2019). Tindak Tutur Masyarakat di Desa Lawangan Daya Kecamatan Pademawu Kabupaten Pamekasan. GHANCARAN: Jurnal Pendidikan Bahasa Dan Sastra Indonesia, 1(1), 41-51. 